\title{
A Review of Nchanga Tailings Dam Operations and Seasonal Assessment of Its Effluent Quality
}

\author{
Ronald Ngulube ${ }^{1, ~}$, Kennedy Nakena Katundu ${ }^{1}, K_{\text {Kenny Nyirenda }}{ }^{2}$, Anthony Siakamba ${ }^{3}$ \\ ${ }^{1}$ Department of Chemical Engineering, Copperbelt University, Kitwe, Zambia \\ ${ }^{2}$ Department of Geology and Survey, Copperbelt University, Kitwe, Zambia \\ ${ }^{3}$ Tailings Leach Plant, Nchanga IBU, Konkola Copper Mines Plc, Chingola Zambia
}

Email address:

ronald.ngulube@cbu.ac.zm (R. Ngulube), kennedy.katundu@cbu.ac.zm (K. N. Katundu), kenny.nyirenda@cbu.ac.zm (K. Nyirenda), anthony.siakamba@kcm.co.zm (A. Siakamba)

${ }^{*}$ Corresponding author

\section{To cite this article:}

Ronald Ngulube, Kennedy Nakena Katundu, Kenny Nyirenda, Anthony Siakamba. A Review of Nchanga Tailings Dam Operations and Seasonal Assessment of Its Effluent Quality. American Journal of Environmental Protection. Vol. 5, No. 4, 2016, pp. 90-96. doi: 10.11648/j.ajep.20160504.13

Received: June 3, 2016; Accepted: June 21, 2016; Published: July 6, 2016

\begin{abstract}
The Nchanga tailings dam, a reservoir of mine waste from Konkola Copper Mines (KCM) operations in Zambia, discharges its effluent into the local Muntimpa stream. The Muntimpa stream, a possible source of drinking and domestic water for the local population, flows into Mwambashi stream which subsequently discharges into Kafue river. The Kafue river is a significant support of economic development in Zambia and is a source of $40 \%$ of drinking water for the cities with about $50 \%$ of the population living in the catchment. This study looks at an overview of the operations of Nchanga tailings dam and assesses the levels of $\mathrm{pH}, \mathrm{TSS}, \mathrm{TDS}, \mathrm{Cu}, \mathrm{Mn}, \mathrm{Co}$ and $\mathrm{SO}_{4}$ in the effluent discharged in rainy and dry seasons. It also provides possible methods that could be used to lower pollutant levels to below recommended Zambia Environmental Management Agency (ZEMA) limits. To determine the pollutant concentrations, sixty (60) samples were collected from the tailings dam spillway in rainy season (April) and dry season (October) of 2015 and analysed on a daily basis. The results indicated that the average $\mathrm{pH}$, TSS and $\mathrm{Cu}$ levels in the samples from both wet and dry seasons were within the permissible range of 6.0-9.0, below $100 \mathrm{mg} / 1 \mathrm{and} 1.0 \mathrm{mg} / \mathrm{lrespectively.} \mathrm{The}$ TDS average figure $(2658 \pm 331 \mathrm{mg} / \mathrm{l})$ recorded in April was less than the allowable limit while significantly higher value $(4783 \pm 86.6 \mathrm{mg} / \mathrm{l})$ was obtained in October. The concentrations of Mn and Co were significantly high and above ZEMA limits with mean values of $79 \pm 22.1 \mathrm{mg} / \mathrm{l}$ and $11 \pm 5.9 \mathrm{mg} / \mathrm{l}$ for rainy season and $189 \pm 19.2 \mathrm{mg} / \mathrm{l}$ and $19 \pm 1.3 \mathrm{mg} / \mathrm{l}$ for dry season respectively. The $\mathrm{SO}_{4}$ content was observed to be high in both seasons with average figures of $2071 \pm 240 \mathrm{mg} / \mathrm{l}$ in April and $3628 \pm 261 \mathrm{mg} / \mathrm{lin} \mathrm{October}$. It was observed that the levels of all the parameters analysed (with exception of $\mathrm{Cu}$ ) showed seasonal variations attributed to evaporative effects. To minimise contaminants levels in the effluent, it is recommended that the discharged effluent should be restricted in dry season until the levels of dissolved pollutants are sufficiently low in wet season. Recycling of water from the decantation pond of the tailings impoundment back to the main plant is an effective alternative that would eliminate pollution of water bodies. Other methods that could be employed involve the use of chemical and biological treatment technologies.
\end{abstract}

Keywords: Nchanga Tailings Dam, Muntimpa Stream, Mwambashi Stream, Effluent Quality

\section{Introduction}

Zambia is a land-locked country with only one river basin which is essential in the support of economic development. Kafue river from its upper course down to its confluence with the Zambezi river is surrounded by various activities such as mining industries, agricultural schemes, and fishing industries.
Furthermore, the Kafue river is a source of $40 \%$ drinking water for the cities and about $50 \%$ of the population lives in the catchment area [1, 2]. Recently, there has been a growing concern in the quality of aquatic environment of Kafue river owing to mining activities in the Copperbelt province of Zambia. The mining industries discharge their effluent to the surface waters of streams and reach groundwater through percolation. It 
is reported that surface and groundwater contamination by the chemical contaminants in the Copperbelt is mainly as a result of discharge and leakages from tailing dams [3].

Tailings dam construction in recent years has increasingly been driven by environmental factors and not to the benefit of engineering safety of tailings dam structures [4]. Safe disposal of tailings is generally regarded as one of the largest environmental challenges and a major expense for mining companies worldwide.

Tailings from the mines mainly contain sulphides and metals such as $\mathrm{Cu}, \mathrm{Fe}, \mathrm{Mn}, \mathrm{Co}, \mathrm{Zn}$ etc that occur naturally in the ore body. The sulphides get oxidized when tailings are exposed to air and when in contact with water, a process known as Acid Mine Drainage (AMD) occurs [4]. In this process, environmentally toxic sulphuric acid is generated which enhances metal leaching in tailings.

Tailings dam operation is reported to be one of the most important anthropogenic sources of pollution that negatively influence the nearby environment. This is mainly caused by tailings dams discharging effluent with high levels of pollutants as well as leakage and seepage of toxins [5]. The discharge of large quantities of mining effluent, with high levels of heavy metals into water bodies may cause death of aquatic life, short and long term toxicity such as reduced growth and development on animals, organ damage, cancer, as well as destruction of habitant from suspended solids [6, 7]. In addition, high levels of pollutants have a serious upset on the water treatment plants in terms of operating cost as they require advanced and specialized treatment units to reduce contaminant levels. Reference [8] reported that a US\$9.5 million project of Mwambashi Pump Station, reconstructed by Nkana Water and Sewarage Company (NWSC), is still non-operational for over three (3) years because of high levels of $\mathrm{SO}_{4}$ and heavy metal in Mwambashi stream, above ZEMA permissible maximum limits. This has led to erratic supply of water to Kalulushi, Chimwemwe and Garneton areas and forced the residents to fetch water from streams and shallow wells. In many developing countries, mining industries dispose of their effluents without adequate characterization, quantification and treatment due to operational and technological constraints [9]. This study looks at an overview of the operational challenges of Nchanga mine tailings dam and determines the levels of $\mathrm{pH}$, TSS, TDS, $\mathrm{Cu}, \mathrm{Mn}, \mathrm{Co}$ and $\mathrm{SO}_{4}$ in the effluent discharged. It also provides possible methods that could be used to lower pollutant levels to below recommended statutory limits.

\section{Site Location and Description}

The Nchanga Tailings Dam also known as Muntimpa Tailings Storage Facility (MTSF) is situated in the Muntimpa Valley, about three (3) Km East of Mimbula Open Pit and thirteen (13) Km South of the Nchanga main mine plant area. The main embankment, referred to as the South Wall, is located on the Muntimpa Stream, close to its confluence with the Kasompe Stream on the East and an unnamed tributary to the West. The disposal area extends northwards from the main embankment and is flanked by confining embankments on both the eastern and western sides. Rising ground and a confining earth-fill embankment form the northern boundary. At the northern end of the depository is the Break Pressure Tank (BPT) which receives the tailings that are pumped from the main plant. The footprint of the MTSF is approximately 1600 hectares (ha).

\section{Nchanga Tailings Dam Operations}

Storage of tailings at MTSF started in 1978. The operation consists of dam wall building using cyclones, discharging of effluent water into the environment through the spillway, draining of the water from the solids through filters and erosion control through revegetation. The confining walls are raised using cyclone coarse tailings while the overflow material is deposited behind the walls to develop the beach and pools so as to enable safe containment of the tailings and provide adequate freeboard. The prime objective of MTSF is safe storage of tailings with minimal environmental impact (It should be erosion resistant, non-polluting and stable structure) [10].

The MTSF has an extensive under-drainage system along all its confining walls. Along the eastern and southern flanks, the under-drainage system consists of two longitudinal filters interconnected by a series of transverse filters. The transverse filters pass under the earth-fill toe wall and discharge in the toe drains. The outlets of these filters have a rock protection which is regularly cleared of debris and other loose materials.

Since the commissioning of MTSF, a total of over 422 million tons of tailings has been deposited in the depository. The current design capacity of the depository is about 535 million tons of tailings. To confine this amount of material entails progressive rising of the main dam wall across southern end of the Muntimpa valley as well as construction of relatively low frank embankments along eastern and western sides of the dam. The main embankment level will be highest where it crosses the Muntimpa stream and in this location it will eventually be raised to about $70 \mathrm{~m}$ above original ground level. To the north of the depository, the tailings are impounded by the raising ground at the heads of the three valleys which comprise the dump site.

The deposition of tailings at MTSF currently has been taking place through open end and launders with limited cycloned deposition. This unpleasant situation is as a result of operational constraints such frequent pipe bursts and leaks as the tailings distribution pipelines are old. Failure of the cyclone off-take points is another challenge encountered frequently, which leads to increase in cycloning downtime. Deposition of tailings through launders has led to the depository developing a higher than expected beach in the northern area. This has consequently pushed the pool slightly away from the spillway and towards the southern main embankment thereby compromising on the wall stability. A complete survey of the whole tailings beach is required in order to ascertain the correct beach profile. Furthermore, an aerial topographic and hydrographic surveys need to be done to assess and determine the profile of the pond and tailings surface beneath. This will assist in developing a long term tailings deposition plan. 


\section{Method}

The study involved collection of sixty samples from the tailings dam spillway in both rainy season (April) and dry season (October) of 2015. To determine the TSS, a $0.45 \mu \mathrm{m}$ filter paper was used. The filter paper was placed on a funned connected to a suction pump. A $100 \mathrm{ml}$ of water was poured into the funnel and suction was exerted on the funnel by forcing the water to pass through the filter paper. The filter paper with suspended solids was then dried at $105^{\circ} \mathrm{C}$ in an oven and re-weighed to measure the mass of suspended solids and filter paper. The TSS was calculated using equation 1 below. From the filtrate obtained during the determination of TSS, $50 \mathrm{ml}$ of water was pipetted onto a petri dish. This was placed on a heater until all the water had evaporated. The mass of the empty petri dish was measured before water was put in the beaker. The mass of the petri dish after all the water had evaporated was measured and recorded. The difference between the mass of the clean empty petri dish and that of the petri dish with residues after drying off the water was taken to be the mass of the TDS. The concentration of TDS was calculated as shown in equation 2. To determine the concentration of $\mathrm{SO}_{4}$, a Gravimetric Method with ignition of residue was used. In this method, the amount of $\mathrm{SO}_{4}$ was determined by precipitation of $\mathrm{BaSO}_{4}$ in $\mathrm{H}_{2} \mathrm{SO}_{4}$ acid solution. The precipitate was filtered, washed, ignited and weighed as $\mathrm{BaSO}_{4}$. The concentration of the metals in filtered water was determined using the Atomic Absorption Spectrophotometer. The metals determined were $\mathrm{Cu}, \mathrm{Co}$ and $\mathrm{Mn}$. For this analysis, the wavelength for metal detection was established followed by aspiration of solution into the flame for vaporation. The energy absorbed by the metals was then measured and the concentration was read from the calibration curve obtained by analysing standard solutions. The absorption of energy followed Beer Lambert's Law [11]. The $\mathrm{pH}$ of each sample collected at each point was measured using the $\mathrm{pH}$ meter.

$$
T S S=\frac{\text { Mass of filter paper and suspended solids-Mass of filter paper }(\mathrm{mg})}{\text { Volume of } \text { water filtered }(l)}
$$

$$
T D S=\frac{\text { Mass of residues after evaporation of water }(\mathrm{mg})}{\text { Volume of } \text { water evaporated }(\mathrm{ml})} \times 100\left(\frac{\mathrm{ml}}{\mathrm{l}}\right)
$$

\section{Results and Discussion}

\subsection{Statistical Analysis}

Statistics is used in analysing the results in this study and average figures are expressed as mean values $\pm \mathrm{SD}$.

\subsection{Preliminary Analysis}

Table 1 and 2 show the summary of the results of effluent parameters analysed. The samples were analysed for seven parameters. The minimum, average and maximum values of each parameter relative to its permissible value (s) are shown in the tables below. The results of the analyses showed that the average $\mathrm{pH}$ values of $7.1 \pm 0.31$ and $7.2 \pm 0.28$ in wet and dry season respectively were obtained. From the results it can be observed that all the values of $\mathrm{pH}$ for all the samples complied with the prescribed guidelines for effluent discharge. The mean values of TSS for samples collected in rainy and dry seasons were relatively low $(51 \pm 40.1 \mathrm{mg} / \mathrm{l}$ and $62 \pm 34.6 \mathrm{mg} / 1$ respectively) and within ZEMA permissible limits. The TDS average figure $(2658 \pm 331 \mathrm{mg} / \mathrm{l})$ recorded in April was less than the allowable limit while significantly higher value $(4783 \pm 86.6 \mathrm{mg} / \mathrm{l})$ was obtained in October. The mean values of $\mathrm{Cu}$ concentration in both seasons fell within ZEMA maximum tolerable level of less than $1.5 \mathrm{mg} / \mathrm{l}$. The concentrations of $\mathrm{Mn}$ and Co were significantly high with average values of $79 \pm 22.1 \mathrm{mg} / \mathrm{l}$ and $11 \pm 5.9 \mathrm{mg} / 1$ for rainy season and $189 \pm 19.2 \mathrm{mg} / \mathrm{l}$ and $19 \pm 1.3 \mathrm{mg} / \mathrm{l}$ for dry season respectively. The $\mathrm{SO}_{4}$ content was observed to be high in both seasons with mean values of $2071 \pm 240 \mathrm{mg} / \mathrm{l}$ in April and $3628 \pm 261 \mathrm{mg} / \mathrm{l}$ in October. The average values of $\mathrm{Mn}, \mathrm{Co}$ and $\mathrm{SO}_{4}$ were far above ZEMA acceptable limits of 1.0, 1.0 and $1500 \mathrm{mg} / 1$ respectively. The levels of all the parameters analysed (with exception of $\mathrm{Cu}$ ) were observed to be relatively high in dry season compared to wet season.

Table 1. Summary of results obtained from samples collected in rainy season.

\begin{tabular}{llllll}
\hline Parameters & Min & Mean & Max & Permissible Value & SD \\
\hline $\mathrm{pH}$ & 6.0 & 7.1 & 7.7 & $6.0-9.0$ & \pm 0.31 \\
Total Suspended Solids (mg/l) & 8 & 51 & 175 & 100 & \pm 40.1 \\
Total Dissolved Solids (mg/l) & 2345 & 2658 & 3815 & 3000 & \pm 331 \\
Copper (mg/l) & 0.01 & 0.57 & 3.16 & 1.5 & \pm 0.59 \\
Manganese (mg/l) & 62 & 79 & 177 & 1.0 & \pm 22.1 \\
Cobalt (mg/l) & 7 & 11 & 40 & 1.0 & \pm 5.9 \\
Dissolved Sulphate (mg/l) & 1730 & 2071 & 2752 & 1500 & \pm 240 \\
\hline
\end{tabular}

Table 2. Summary of results obtained from samples collected in dry season.

\begin{tabular}{lllll}
\hline Parameters & Min & Mean & Max & Permissible Value \\
\hline $\mathrm{pH}$ & 7.0 & 7.2 & 7.9 & $6.0-9.0$ \\
Total Suspended Solids (mg/l) & 20 & 62 & 154 & 100 \\
Total Dissolved Solids (mg/l) & 4634 & 4783 & 4872 & 3000 \\
Copper (mg/l) & 0.03 & 0.38 & 1.04 & 1.5 \\
Manganese (mg/l) & 158 & 189 & 221 & 1.0 \\
Cobalt (mg/l) & 17 & 19 & 21 & 1.0 \\
Dissolved Sulphate (mg/l) & 3040 & 3628 & 3945 & 1500 \\
\hline
\end{tabular}




\subsection{Analysis of Parameters}

For proper understanding of the analysis of effluent parameters, an overview of the mining operation has to be understood. The Nchanga mine operates an Open Pit (OP), Underground (UG) mine, Concentrator, Smelter and Tailings Leach Plant. The metal ore at OP and UG exist in form of metal oxide ores and pyrite ores. The metal oxide ores consists of a compound of metal with oxygen while pyrite ores involve metal ions in a compound with sulphur.

In order to obtain a metal concentrate, ore is separated from waste rock by comminution, gravity process and flotation. These processes are carried out in water, the consumption of which is typically between 3 and $15 \mathrm{~cm}^{3}$ per one metric tonne of ore [12]. The main objective of the processing plants is to recover the economically valuable copper from the gangue minerals. According to [13] the waste waters deriving from ore processing plants are contaminated with insoluble substances, predominantly waste sludge (finely ground waste rock), soluble substances, which are extracted from the ore (heavy metals, sulphates) and chemical used in the flotation process, smelter and tailings leach plant. Flotation processes feature ethylxanthogenates, which is very toxic, cyanides, the salts of heavy metals, slacked lime and sulphuric acid. The metal ore is further subjected to pyrometallurgy (at high temperatures) and hydrometallurgy or leach plant (processes in the aqueous media). The main stages of hydrometallurgy involve leaching, solvent extraction and electrowinning processes which use various solvents (water, acids, alkalis, salts, organic solvents or extractants). Since these metallurgical processes are carried out in aqueous media (or aqueous phase), there is, however, greater potential for contamination of large volumes of water [14]. The final tails is then neutralized with lime prior to disposal to MTSF.

The $\mathrm{pH}$ of the discharged effluent recorded in this study could be described as slightly alkaline and is within the ZEMA standard for discharge into the environment. This suggests that the effluent exerts no negative effect on the environment as far as $\mathrm{pH}$ is concerned. The stability in $\mathrm{pH}$ during the study period could be attributed to well-controlled process of neutralization on the main plant. The MTSF is an effective settler, as evident from the mean figures of TSS. The fluctuations in the levels of TSS as can be seen from minimum and maximum figures could be as a result of deposition taking place through launders as opposed to cycloned deposition. As a result, there is insufficient residence time for solids to settle. Copper is one of the most toxic metals to aquatic organisms and ecosystems and it is moderately soluble in water and binds easily to sediments and organic matter [7]. However, the $\mathrm{Cu}$ content in the discharged effluent could be described as not toxic to aquatic life as such would not cause any damage to aquatic organism. The low levels of $\mathrm{Cu}$ recorded in both seasons are as a result of improved $\mathrm{Cu}$ recovery efficiencies at concentrator and tailings leach plant.

TDS is a measure of inorganic anions and cations dissolved in water. The anions include $\mathrm{SO}_{4}{ }^{2-}, \mathrm{CO}_{3}{ }^{-}, \mathrm{NO}_{3}{ }^{-}$, and $\mathrm{Cl}^{-}$etc. while the cations comprise $\mathrm{Ca}^{+}, \mathrm{Na}^{+}$and other dissolved metals. Thus, $\mathrm{SO}_{4}$ is a constituent of TDS and may form salts with dissolved cations. High content of TDS can cause toxicity to aquatic life through increases in salinity and changes in the ionic composition of the water. The exposure to high levels of $\mathrm{Mn}$ and $\mathrm{Co}$ has been reported to cause neurological and heart damages respectively to human beings [15]. $\mathrm{SO}_{4}$ is generally considered to be non toxic but consumption of high amounts may result in intestinal discomfort, diarrhea and consequently dehydration [16]. The stabilization of mineral assemblage in the tailings is critical in dams operation in order to avoid generation of TDS, $\mathrm{Mn}, \mathrm{Co}$ and $\mathrm{SO}_{4}$. $[17,18]$ reported that oxidation of the mineral assemblage in tailings dam can be brought about by atmospheric oxygen as well as geochemical conditions of the disposal site. These processes are associated with low $\mathrm{pH}$ in the range of $2-4$. Oxidation of sulphides to sulphates by acidic generation and release of metals can also be caused by exposure of sulphide minerals to water, carbon dioxide and soluble chemical species during mining and mineral processing activities. However, the high levels of TDS, Mn and $\mathrm{SO}_{4}$ in the effluent discharged from MTSF could not be attributed to AMD as the pHs for all the samples analyzed were slightly alkaline in nature. The study conducted by [4] showed that AMD is not a sufficient condition in itself if there is enough quantity of alkaline minerals present in the waste to act as buffering minerals. Reference [19] has also shown that the concentrations of chemical species depend to some extent on the solubility of gypsum or anhydrite often present in ore deposit. Furthermore, the neutralization reaction also generate cations such as $\mathrm{Fe}, \mathrm{Ca}, \mathrm{Co}, \mathrm{Mn}$ etc. into the solution which then result in formation of sulphate complexes, so that higher concentrations of sulphate can stay in solution, than can be explained by the solubility of gypsum alone [17]. The high concentration of TDS, Mn, Co and $\mathrm{SO}_{4}$ could be an indication of oxidation of sulphide minerals in the main plant as a result of sulphuric acid. Though, there is need to further investigate the levels of chemical pollutants in the main plants. The seasonal variation in the concentration of the parameters analysed could be attributed to evaporation of water in the MTSF. Reference [19] also reported a strong increase in the levels of chemical species in active tailings of porphyry copper deposit with an annual trend to increase towards the end of dry season. The variation was attributed to the geochemical process such as temperature drop.

\section{Treatment Methods for Mine Effluent}

Metal and sulphate contaminated effluent produced by mineral processing plants, occurs at an estimated $70 \%$ of the world's mine sites, making it one of the mining industry's most significant environmental and financial liabilities [20]. As environmental regulations tighten globally, leading mining companies are proactively looking for ways to enhance the sustainability of their mine operations, and 
reduce potential long-term liabilities [9]. In recent years, sulphide-based process technologies for metal removal have been successfully implemented at mine sites in Canada, the US, Mexico, Australia, China and South Africa and extensively piloted in Canada and Chile [21]. These technologies offer significant benefits as they are capable of removing metals and sulphate to very low levels that meet regulatory standards for discharge or re-use. This approach offers a sustainable business model that delivers overall improvements to the environment [20]. The following are the technologies that can be employed in treating mining effluent.

\subsection{Neutralisation and Precipitation}

The principle of neutralization using lime and limestone lies in the insolubility of metals in alkaline conditions. By controlling $\mathrm{pH}$ to a typical setpoint of $6-9$, metals such as $\mathrm{Cu}$, $\mathrm{Mn}, \mathrm{Fe}$ and $\mathrm{Zn}$ can be precipitated. Other metals such as Co, $\mathrm{Ni}$ and $\mathrm{Cd}$ require a higher $\mathrm{pH}$, in the range of $10-12$ to effectively precipitate the hydroxides [22]. This technique can also be used for the removal of sulphate through precipitation of gypsum $\left(\mathrm{CaSO}_{4} \cdot 2 \mathrm{H}_{2} \mathrm{O}\right)$. The levels to which $\mathrm{SO}_{4}$ concentration are reduced are controlled by the solubility of gypsum, which, depending on the composition and ionic strength of the solution, which can be as low as $1200 \mathrm{mg} / \mathrm{l}$ [23]. More recently, an integrated lime/limestone process was developed that can reduce metal and sulphate levels to below ZEMA limts. The process consists of three steps; 1) Limestone neutralisation to raise $\mathrm{pH}$ resulting in $\mathrm{CO}_{2}$ production, and metal and gypsum precipitation. 2) Lime treatment to raise the $\mathrm{pH}$ to 12 for $\mathrm{Mg}(\mathrm{OH})_{2}$, metal and enhanced gypsum precipitation and, 3) $\mathrm{pH}$ adjustment with $\mathrm{CO}_{2}$ (recovered from phase 1) with concurrent $\mathrm{CaCO}_{3}$ precipitation $[24,25]$. The precipitates are formed individually as minuscule particles that can settle. This method is being used at Mine water at the Navigation coalmine near Witbank in South Africa [23].

\subsection{Reverse Osmosis}

This process relies on a semi-permeable membrane which separates a strong solution and a dilute solution. The greater the concentration difference across the membrane, the higher the tendency for water to permeate to the concentrated solution [26]. In this process, an external hydraulic pressure is applied to the effluent (saline brine) thus forcing it through the membrane against osmotic pressure. To avoid challenges that can result from precipitation and high osmotic pressure, suspended solids and microbial growth, the feed effluent must be preheated and portion of the feed is discharged without passing through the membrane [27]. A pilot plant for reverse osmosis has been operated in South Africa for 5000 hours and had a $96 \%$ water recovery reducing metals to less than statutory limits and $\mathrm{SO}_{4}$ from over $6000 \mathrm{mg} / \mathrm{L}$ to as low as 150 $\mathrm{mg} / \mathrm{l}$. Reference [28] has also reported that a reverse osmosis plant is in operational at a West Basin Plant, California where $50,000 \mathrm{~m}^{3} /$ day of effluent is being treated.

\subsection{Biological Process}

Biological removal of metals and sulphate in mining effluent involves the use of biological techniques. It is a selective technique that utilises microorganisms and plants. In bioremediation, the microbe (s) change the metal chemistry and mobility through reduction, accumulation, mobilisation or immobilization [29]. According to [30] the major groups of microorganisms that have been implicated in metal remediation are bacteria (such as Bacillus sp, Citrobacter, Cupriavidus etc. In phytoremediation, plants play a great role in the biological process as they break down, reduce, degrade and remove these contaminants using various parts, such as the root, leaves, stomata, cell wall and the shoot $[31,32]$. The most common phytoremediation processes are rhizofiltration, phytostabilization, phytoextraction, phytovolitazation, phytodegradation and rhizodegradation [33]. Biological treatment process was first implemented at commercial scale by Budelco (The Netherlands) in the early 1990s and recently it has emerged as an alternative and sustainable technology with great potentials to provide attractive economic benefits to the mining industries compared to chemical treatment processes [34, 35].

\subsection{Biochemical Process}

This process involves both a biological and a chemical stage [20]. In the biological stage sulphur-reducing bacteria contained in an anaerobic bioreactor produce $\mathrm{H}_{2} \mathrm{~S}$ gas. The gas is transferred to a contactor tank that contains the effluent to be treated. In the chemical stage, the solution chemistry in the tank is adjusted to selectively precipitate metals as pure metal sulphides. The precipitated metals and treated effluent are pumped to a clarifier tank where the water is separated from the metal solids and discharged or recycled. To recover multiple types of metals, separate contactor and clarifier tanks are set up in series. This process is being used at Jiangxi Copper's Dexing copper mine, in southeastern China [21].

\subsection{Other Methods}

Other various technologies that can be used in treating mining effluents include; constructed wetland method, ion exchange chromatography and electrical dialysis reversal (ED) etc. The wetland method covers a big area, treatment effect influenced greatly by environment. Ion exchange method involves exchange of ions or molecules between solid and liquid with no substantial change to the solid structure. The targeted ions are essentially removed from the effluent and get attached to the solid structure in exchange for another ion. An ED uses membrane separation technique based on the migration of ions through ion-selective membrane as a result of an electrical force [36].

\section{Conclusion and Recommendation}

The study showed that Konkola Copper Mines plc is discharging its effluent from MTSF into the water bodies with levels of $\mathrm{pH}$, TSS and $\mathrm{Cu}$ within ZEMA discharge limits while concentrations of $\mathrm{Mn}, \mathrm{Co}$ and $\mathrm{SO}_{4}$ exceeding the limits. The 
results further revealed that there is seasonal variation in the levels of the parameters analysed. The company needs to focus its effort on improving dams operations or treat the effluent with a view of reducing the concentration of contaminants prior to discharge to the environment.

There are several ways in which the operations can be improved. One of the methods could be to restrict the discharge of effluent from the spillway until the concentrations of dissolved pollutants are sufficiently low. This could be achieved if the dam's course wall/beach interface could be kept with a minimum freeboard of at least $0.5 \mathrm{~m}$ above the surface of the pool. This would prevent the pool from reaching the course embankment zone which would compromise on walls stability. After rainy season, the pool level could be kept as low as possible. With the reduced dilution of dissolved pollutants concentration, the levels would increase to unacceptable figures and at this stage the spillway could then be closed. This would also give enough residence time for suspended solids to settle. Recycling of water from the decantation pond of the tailings impoundment back to the main plant is also another method that could be employed. This would minimize the amount of discharged effluent at the same time recover industrial water for plant use. Though laboratory test works need to be carried out to ascertain the impact of the recycled water on floatation efficiency.

$\mathrm{KCM}$ can employ the widely used methods to remove or minimize pollutants in mine effluent. These methods include; neutralization and precipitation, reverse osmosis, biological and biochemical processes. Biological process has recently emerged as an alternative and sustainable technology owing to its economic benefits compared to chemical treatment processes.

\section{Acknowledgement}

We would like to earnestly express our gratitude to Konkola Copper Mines Plc for allowing us to carry out this study at its premises. We are grateful to the Copperbelt University for providing us with facilities that were used during the study. We also thank Mr. Chima Zebedia, Disposal Dam and Tailings Reclamation Manager and Mr. Kombe Mwaba, Environmental Coordinator at Tailings Leach Plant - Konkola Copper Mines, who provided insight that greatly assisted the research.

\section{References}

[1] L. Norrgren, U. Pettersson, S. Orn, P. Bergqvist. (2000). Environmental monitoring of the Kafue River, located in the Copperbelt, Zambia. Archives of Environmental Contamination and Toxicology. [Online] 38. pp. 334-341. Available: http://www.ncbi.nlm.nih.gov/pubmed/10667931

[2] U. T. Pettersson, J. Ingri, P. S. Andersson. (2000). Hydrogeochemical processes in the Kafue River upstream from the Copperbelt mining area, Zambia. Aquatic Geochemistry. [Online] 6. pp. 385-411. Available: http://www.ncbi.nlm.nih.gov/pubmed/10667931

[3] Environmental Council of Zambia, "Zambia Environment Outlook 3," 2008.
[4] K. Fytas, J. Hadjigeorgiou. (1994). An assessment of acid rock drainage continuous monitoring technology. Enviromental Geology. [Online] 1. pp. 33-40. Available: http://link.springer.com/article/10.1007\%2FBF01061828\#pag e-1

[5] K. Vanderlinden, R. Ordonez, M. J. Polo, J. V. Giraldez. (2006). Mapping residual pyrite after a mine spill using non co-located spatiotemporal observations. Journal Environment Quality. [Online] $35 . \quad$ pp. 21-36. Available: http://www.ncbi.nlm.nih.gov/pubmed/16391274

[6] K. Burnod-Requia, "Rapid environmental assessment of the Tisza river basin," United Nations Environment Programme, 2004.

[7] C. Kraft, W. Tumpling, D. W. Zachmann. (2006). The effects of mining in Northern Romania on the heavy metal distribution in sediments of the rivers Szamos and Tisza (Hungary). Acta hidrochim.hydrobiol. [Online] 34. pp. 257-264. Available: http://onlinelibrary.wiley.com/doi/10.1002/aheh.200400622/ab stract

[8] S. Mwale, "Zambia: Kitwe, Kalulushi Water Plants to Reopen-NWSC," Times of Zambia, pp. 15, 30 November 2013 Available: http://allafrica.com/stories/201312010115.html

[9] M. A. Acheampong, R. J. Meulepas, P. N. Lens. (2010). Removal of heavy metals and cyanide from gold mine wastewater. Journal of Chemical Technology \& Biotechnology. [Online] 85. pp. 590-613. Available: http://onlinelibrary.wiley.com/doi/10.1002/jctb.2358/full

[10] Konkola Copper Mines Plc, “Tailings Leach Plant Internal Technical Reports' 2011.

[11] D. A. Skoog and D. M. West, Fundamentals of Analytical Chemistry. $3^{\text {rd }}$ Ed. Holt, Rinehart and Winston, New York. pp. 296-298, 505-508.

[12] R. W. Lawrence, P. B. Marchant, M. Bratty, D. Ratochvil, "Applications for biogenic sulphide reagent for copper recovery in copper and gold hydrometallurgical operations", Proc. $\mathrm{Cu}$ 2007, the 6th Copper/Cobre Conference, August 25-30, 2007, Toronto, Canada, 2007.

[13] J. S. Hadzi, M. Maletić, A. Dimitrov, D. Slavkov, P. Paunović, "Desalination", 1-7. 2006.

[14] N. Papassiopi, E. Mylona, A. Xenidis, I. Paspaliaris. Scientific Committee of Mining and Metallurgical Engineers, Vol. A. 2000 .

[15] J. Singh, S. K. Upadhyay, R. K. Pathak, V. Gupta. (2011). Accumulation of heavy metals in soil and paddy crop (Oryza sativa), irrigated with water of Ramgarh Lake, Gorakhpur, UP, India. Toxicol. Environ. Chem. [Online] 93 (3) pp. 462-473.

[16] W. D. Heizer, R. S. Sandler, E. Seal, S. C. Murray, M. G. Busby, B. G. Schliebe, S. N. Pusek. (1997). Intestinal Effects of Sulfate in Drinking Water on Normal Human Subjects. Digestive Diseases and Sciences. [Online] 44 pp. 1055-1061. Availvable: http://link.springer.com/article/10.1023\%2FA\%3A1018801522760.

[17] J. Smuda, B. Dold, J. E. Spangenberg, K. Friese, M. R. Kobek, C. A. Bustos, H. R. Pfeifer. (2014). Element cycling during the transition from alkaline to acidic environment in an active porphyry copper tailings impoundment, Chuquicamata, Chile. Journal of Geochemical Exploration. [Online] 140. pp. 23-40. Available:

http://www.sciencedirect.com/science/article/pii/S037567421 4000156 
[18] B. Dold, N. Diaby, J. E. Spangenberg. (2011). Remediation of a marine shore tailings deposit and the importance of water-rock interaction on element cycling in the coastal aquifer. Environ. Sci. Technol. [Online] 45. pp. 4876-4883. Available: http://www.ncbi.nlm.nih.gov/pubmed/21563818

[19] B. Dold. (2014). Evolution of Acid Mine Drainage Formation in Sulphidic. Minerals. [Online] 14. pp. 621-641. Available: http://www.mdpi.com/2075-163X/4/3/621

[20] R. W. Lawrence, D. Kratochvil, D. Ramey, “A new commercial metal recovery technology utilizing on-site biological $\mathrm{H}_{2} \mathrm{~S}$ production", Proc. HydroCopper $-3^{\text {rd }}$ International Workshop on Copper Hydrometallurgy. Santiago, Chile, November 23-25. 2005.

[21] M. Bratty, R. W. Lawrence, D. Kratochvil, "Reducing water treatment costs while meeting the challenge of environmental compliance for the mining industry", Proc. WIM 2008-1st International Congress on Water Management in the Mining Industry. Santiago, Chile, July 9-11, 2008.

[22] B. Aubé, B. Arseneault, "In-Pit Mine Drainage Treatment System in a Northern Climate", In Proceedings for Sudbury 2003 Mining and the Environment Conference, May 25-28 2003. Available: http://www.enviraube.com/images/raglan.pdf

[23] A. J. Geldenhuys, J. P. Maree, M. de Beer, P. Hlabela, “An Integrated limestone lime process for partial sulphate removal", Paper presented at the conference on Environmentally Responsible Mining in South Africa, Sept 2001.

[24] M. Bratty, R. W. Lawrence, D. Kratochvil, P. B. Marchant, "Applications of biological $\mathrm{H}_{2} \mathrm{~S}$ production from elemental sulphur in the treatment of heavy metal pollution including acid rock drainage", Proc. International Symposium on Acid Rock Drainage (ICARD), St. Louis, March 26, 29, 2006.

[25] R. D. Ludwig, R. G. McGregor, D. W. Blowes, S. G. Benner, K. Mountjoy. (2002). A peamable reactive barrier for treatment of heavy metals. Ground Water 40: 59-66.

[26] Meeting challenges of heavy metal pollution in aqueous solutions. Current science, 78 (8): 967-973.

[27] G. C. Miller, T. K. Tsukamoto. (2002). Remediation of Zinc at the Equity Silver Mine Unpublished Report Placer Dome, Canada.

[28] K. Alexander, S. Alt, E. Owens, M. Patel, L. McGovern, "Low fouling reverse osmosis membranes evidence to the contrary on microfiltered secondary effluent", Proc. AWWA Memb. Technology Conference, 2003.

[29] R. Faryal, A. Hameed A (2005). Isolation and characterization of various fungal strains from textile effluent for their use in bioremediation. Pakistani Journal of Botany, 37 (4): 1003-1008.

[30] M. A. Dias, I. C. A. Lacerda, P. F. Pimentel, H. F. Castro, C. A. Rosa. (2002). Removal of heavy metals by an Aspergillus terreus strain immobilized in a polyurethane matrix. Letters in Applied Microbiology, 34: 46-50.

[31] P. Rajendran, J. Muthukristnan, P. Gunasekaran. (2003). Microbes in heavy metal remediation. Indian Journal of Experimental Biology, 41: 935-944.

[32] K. Ramasamy B. Kamaludeen, P. B. Sara. (2006). Bioremediation of Metals: Microbial

[33] P. G. Ana, O. S. Antonio, M. L. Paula. (2009). Remediation of heavy metal contaminated soils: phytoremediation as a potentially promising clean-up Technology. Journal of Environmental Science and Technology, 39 (1): 622-654

[34] M. Bratty, R. Lawrence, D. Kratochvil, B. Marchant, "Applications of Biological $\mathrm{H}_{2} \mathrm{~S}$ Production from Elemental Sulfur in the Treatment of Heavy Metal Pollution Including Acid Rock Drainage", $7^{\text {th }}$ ICARD 'Leadership: Gateway to the Future, 2006.

[35] O. B. Akpor, M. Muchie. (2010). Remediation of heavy metals in drinking water and wastewater treatment systems: Processes and applications. International Journal of the Physical Sciences. [Online] 5 (12). pp. 1807-1817. Available: http://www.academicjournals.org/article/article1380814369_A kpor\%20and\%20Muchie.pdf

[36] O. B. Akpor, G. O. Ohiobor, T. D. Olaolu. (2010). Heavy Metal Pollutants in Wastewater Effluents: Sources, Effects and Remediation. Advances in Bioscience and Bioengineering. Vol. 2, No. 4, pp. 37-43.

\section{Biography}

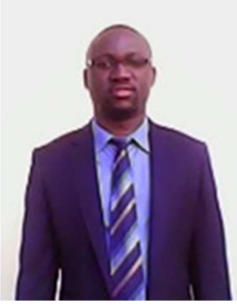

Ronald Ngulube is currently working as Lecturer/Consultant at the Copperbelt University, Zambia. He is a holder of MSc in Environmental Biotechnology at the University of Westminster, United Kingdom and BEng in Chemical Engineering from Copperbelt University, Zambia. Mr. Ngulube has over six years of industrial experience in hydrometallurgy and worked as Assistant Plant Manager, Senior Process Engineer, and Project Metallurgist among others at Konkola Copper Mines Plc, Zambia. His main research interest is in; treatment of copper sulphide ores by bioleaching technique, bioremediation of mine effluent by sulfate reducing bacteria and application of genetic engineering in biofuels production. 